Patricia Feise-Mahnkopp*

\title{
Transliminality: Comparing Mystical and Psychotic Experiences on Psycho- Phenomenological Grounds
}

https://doi.org/10.1515/opth-2020-0140

received October 1, 2020; accepted November 16, 2020

\begin{abstract}
On a phenomenal level, no differences between the mystical and the initial sequence of psychotic experience are to be found. Both are characterized by transliminality (i.e., an experience of consciousness transcending both the psychophysical and the rational realms). However, the situation is different if we integrate psychodynamic implications before and after those experiences into the comparison. One difference on this level is that the mystical experience (if it meets sufficient ego stability) primarily offers personality-strengthening potential. In contrast, transliminality, which occurs in the course of psychotic experience (if it encounters insufficient ego-stability or a pronounced vulnerability), primarily offers personality-weakening potential. However, if the therapeutic process succeeds in setting ego-stabilizing impulses (or eliminating thought and affect disorders which are typical for psychoses of the schizophrenic spectrum), a conscious incorporation of the transliminal experience into the further therapeutic process proves to be helpful, too. The essential philosophical and therapeutic significance of the connections analyzed here are reflected on with the help of philosophical and psycho(patho)logical phenomenology, in particular with the writings of Husserl's and Pfänder's pupil Gerda Walther, combined with current theorems of responsive phenomenology. Walther's insights into the (dys-)functionalities of ego-center ("Ichzentrum"), self ("Einbettung des Ichzentrums"), and basic essence ("Grundwesen") in mystical and psychotic experience, with respect to their (meta-)transcendental relationship with divine essence ("göttlicher Wesensgrund") provoke further research questions on the constitutive and therapeutic implications of transliminality in the context of mystical and psychotic experience.
\end{abstract}

Keywords: phenomenology, mystical experience, psycho(patho)logy, therapy

\section{Preliminary remarks}

In his Varieties of religious experience (1902), William James notes that

[...] religious mysticism is only one-half of mysticism. The other half has no accumulated traditions except which the textbooks on insanity supply. Open any of these, and you will find abundant cases in which 'mystical ideas' are cited as characteristic symptoms of enfeebled or deluded states of mind. ${ }^{1}$

1 James, "Varieties," 384.

\footnotetext{
* Corresponding author: Patricia Feise-Mahnkopp, Department of Education, Institute of Philosophical Education and Aesthetics, Alfter bei Bonn, Germany, e-mail: patricia.feise@alanus.edu
} 
Connected with this, Karl Jaspers states in lapidary style: "Religious experience remains what it is, whether it is carried out by a saint or a mentally ill person, or whether the person experiencing is both in one." In his fundamental study on the psychopathology of conversion, Weitbrecht found analogies between religion and psychopathology on phenomenal grounds (e.g., in schizophrenia there are states of purest clarity and ecstasy, just as in the "unio mystica"). ${ }^{3}$ More recently, Wapnick came to similar conclusions. ${ }^{4}$

But do these observations imply that there is no essential difference between religious experience with mystical experience being understood here as its preeminent expression ${ }^{5}$ - and psychotic experience - here especially of people diagnosed with schizophrenia? And if that is the case, the mystical experience be considered just as pathological as psychotic experience, or is the latter to be understood, like the former, as an inspiring exceptional event?

As a result of the impact of Freudian discourse about "religion as collective obsessive-compulsive disorder," ${ }^{6}$ modern psychology was dominated well into the twentieth century by the former view. ${ }^{7}$ However, a paradigm shift is currently occurring, ${ }^{8}$ such that a revaluation of religious or spiritual ${ }^{9}$ experience and meaning is taking place. ${ }^{10}$ In this respect, research is emerging that considers religious or spiritual experience and meaning as a (non-pathological) part of the life of the human soul and advocates a valuefree incorporation of its results into psychotherapeutic practice. ${ }^{11}$ As a result, religiosity (with the exception of the ecclesiomorphic disorder) is not considered a pathogenic factor per se, but involves a salutogenic factor that needs to be integrated into the multifactorial therapeutic process. Following this logic, the mystical experience is to be understood as an extraordinary religious experience. ${ }^{12}$ Furthermore, recent research advocates for the effects of psychotic experience, which are similar to those of mystical experience, not to be regarded as symptoms of illness, but rather as an extraordinary phenomenon of consciousness, ${ }^{13}$ which has a genuine healing potential. ${ }^{14}$

The thought behind this development can be described by a secularly oriented recourse to Plato. In Phaidros, Plato not only distinguishes between divinely inspired and pathological forms of madness, but also points to the fact that religious ecstasy (besides prophecy, artistic inspiration and philosophical existentialism, the fourth subform of divine madness) can be used as a remedy against pathological forms of madness. ${ }^{15}$ According to Plato, this is characterized by a mental-spiritual ability to overcome bound-

2 Jaspers, Psychopathologie, 90.

3 Weitbrecht, Religionspsychopathologie.

4 Wapnick, "Mysticism and Schizophrenia."

5 Walther, Phänomenologie, 33.

6 Freud, Zwangshandlungen, $183 f$.

7 Cf. Bonelli, "Das psychotherapeutische Unbehagen mit der Religion,” 49; see also Vitz, Psychology as Religion.

8 Utsch, "Religionspsychologische Erklärungen," 40; see also Utsch, "Religiosität und Spiritualität," 68.

9 I use both adjectives to refer to the fact that a person is able to experience a spiritual level that goes beyond the psychophysical and rational implications of consciousness. The term "religious" is preferable when speaking of a trans-worldly spirituality (or specific confessional interpretations of this spirituality), while the term "spiritual" is suitable for naming the experience in question from the perspective of a non-denominational openness, on the one hand, and a post-metaphysical accentuation, on the other (cf. Walach, Beyond a Materialist, 86).

10 Shifting the paradigm does not mean that religious or spiritual experience and the meaning based on it are only now addressed as components of the life of the human soul at all. This was already the case in the early phases of psychological theory formation, as the writings of James, Jung, and Frankl show. Rather, this view is becoming discursively relevant in the course of a spiritual turn that has been spreading since the late 1960s, cf. Utsch, "Religiosität und Spiritualität,” 68.

11 Cf. for example Pargament, Spiritually Integrated Psychotherapy, Aten et al., The Psychology of Religion and Spirituality, Sperry and Shafranske, Spiritually Oriented Psychotherapy, Pargament, APA Handbook of Psychology, Religion and Spirituality. The state of research in German-speaking countries is documented by Utsch et al., Psychotherapie und Spiritualität.

12 Cf. for example Utsch, "Religionspsychologische Erklärungen,” 43.

13 Cf. Clarke, "Psychosis and Spirituality."

14 Williams, Rethinking Madness; see also Feise-Mahnkopp, "Das Heilige erleben.”

15 Plato, "Phaidros." 
aries, ${ }^{16}$ which leads to experiences of consciousness that are characterized by "being out of oneself" or, more precisely, by a state that, in modern terms, transcends the personal ego-consciousness characterized by (more or less pronounced) rationality. In platonic terms, this happens when the transrational part of the psyche comes into contact with the nous, i.e., the (divine-spiritual) reason for being. ${ }^{17}$ This contact does not provide complete knowledge, but it is more adequate than rational knowledge, that is, knowledge based on the $\log o s .{ }^{18}$ To initiate it, the soul must, in a certain sense, take a leap from reason into the vision of enduring ideas (the eidetic world), in which, as highest, the idea of the good is considered (which, in turn, is understood as identical to the divine reason for being). ${ }^{19}$ This act cannot be forced, it can only (passively) be experienced by the soul. The splendor of what is seen inspires the partially excarnated soul; following the experience, the soul that has been transformed in this way - and completely incarnated again - feels the urge to make what has been experienced inspiringly fruitful in a worldly context.

The mystical experience is characterized by such a trans-rational leap and spiritual vision. ${ }^{20}$ Within the philosophical-phenomenological view of mystical experience, both immanent and transcendent positions can be distinguished: modern classics favor a transcendent reading (Stein, Walther), but this can also be understood as an immanent, i.e., secular, experience (e.g., as a transpersonal experience that transcends ego-boundaries). Phenomenologically informed studies on the psychotic experience of people diagnosed with schizophrenia make it clear that states of consciousness may also occur that are characterized by a visionary state of being outside-of-oneself, which is experienced as enthusiasm. ${ }^{21}$ Whether this is understood in the platonic sense, i.e., transcendentally, or in the transpersonal sense, i.e., immanently, the term transliminal that Clarke proposes (which she borrows from Thalbourne) ${ }^{22}$ is well suited to refer to these (exceptional) experiences. ${ }^{23}$

As I will show by comparing two accounts of archetypal experience, despite the similarities that exist on a phenomenal level, essential differences between the mystical and the psychotic experience can also be observed, not with regard to the transliminal nature of the experience, but rather with regard to the effects they have on the respective psyches. This means that in addition to the psycho-phenomenological perspective of analysis, which is considered by interpretative recourse to the writings of Gerda Walther, psychodynamic implications must also be taken into account.

This does not imply a pathologization of the psychotic process; rather, with Menzos, we should speak of a symptomatic functionality of (non-organic) psychotic experience. ${ }^{24}$

Due to the fact that the pathical (in the Greek sense of the word) implications underlying psychotic processes are constitutive for the conditio humana, theorems from humanistic psychology as well as from responsive phenomenology will also have to be addressed. ${ }^{25}$

16 Oehler, Lehre vom Noetischen.

17 Plato, "Phaidros."

18 Ibid.

19 Cf. Strassberg, who emphasizes in his reading of Plato that the use of reason does not lead to the exhibition of the idea of the good as the cause of all being (and thus also as the cause of the logos) (Der Wahnsinn der Philosophie, 58).

20 Except that the interpretation of this vision varies depending on the historical, religious-cultural or spiritual-philosophical background. For example, Taoist, Sufi or Christian mystics interpret their experiences - comparable on a phenomenal level differently. Cf. for example reports by Tschuang-Tse (370-287 BC), a Taoist philosopher, by Râbia (717-801 AD), a Sufi mystic, and by Mechthild of Magdeburg (c. 1207-c. 1282/1294), a Beguine and Christian mystic (Sloterdijk, Mystische Weltliteratur, 254, $66,119)$.

21 Cf. Claridge, "Spiritual Experience."

22 Thalbourne et al., "Transliminality." The term was coined in reference to a "hyper-awareness" in manic-depressive patients. 23 Clarke, "Psychosis;" see also Claridge, "Spiritual Experience." Clarke uses this term to refer to effects on consciousness that fall below or above ordinary (daytime) consciousness. In reference to Plato's transrationality, on the one hand, and Walther's "meta-transcendentalism," on the other, I will use the term narrowly in the present article with respect to its superconscious implications.

24 Mentzos, Lehrbuch.

25 Cf. for example Rogers, Der neue Mensch; Waldenfels, Bruchlinien. 
Analysis and evaluation of the selected accounts of experience emphasize - following to Husserl's double perspective on consciousness - both the psychological and the philosophical implications. The following explanations can therefore be understood as a tightrope walk between both dimensions. ${ }^{26}$

\subsection{Approach}

Two first-person perspective accounts, one from the mystical experience context, the other from the psychotic experience context, will first be analyzed comparatively on a phenomenal level. ${ }^{27}$ The former $^{28}$ was written by philosopher and consciousness researcher Gerda Walther, the latter ${ }^{29}$ by psychologist Peter Chadwick..$^{30}$

Theoretically and methodologically, I orientate myself to Walther's writings, ${ }^{31}$ which are only just starting to be taken into account by researchers, ${ }^{32}$ particularly her main work from 1923, the Phenomenology of Mysticism, ${ }^{33}$ as well as her 1927 article "Zur innenpsychischen Struktur der Schizophrenie." ${ }^{34}$ In addition, approaches borrowed from responsive phenomenology on the pathical character of every experience are taken into account. ${ }^{35}$ In connection with the experience-oriented comparison, the psychodynamics preceding or following the respective transliminal experience are considered comparatively. ${ }^{36}$ The results are first reflected on with the help of the phenomenological concepts mentioned above, and then in the light of psychodynamic approaches (the conceptual and analytical instruments used are briefly outlined in advance). Finally, I raise the

26 Thus, the focus of the epistemological interest of the present article is the "in-between" of the psychological and philosophical significance of transliminal experiences. This does not, however, imply any claim to an exhaustive description of the respective field (e.g., the range of possible philosophical views on transliminality or differential diagnostic clarification of the symptoms classified here as psychotic).

27 It could be objected that selecting accounts that are categorized in these two ways, presupposes the results. This objection is only valid, however, if the phenomenological analysis (which in the sense of the epoche includes the elimination of presuppositions, cf. Husserl, Ideas I, 55) produces nothing more than a simple confirmation of the dual evaluation matrix. That this is not the case will be shown below.

28 Walther, Zum anderen Ufer.

29 Chadwick, "On Not Drinking Soup."

30 Clearly, it is important to keep in mind that memory in some ways transforms experience. However, since the intersubjective comparison of temporally and historically different mystical or transliminal experiences in the context of psychotic experience reveals invariable interfaces on a phenomenal level, subjective memory does not seem to have too distorting an effect.

31 Furthermore, the decision to use as an example of a mystical experience the personal account of a philosopher whose conceptual tools are later used for the analysis of the same account could be criticized as a hermeneutical circle. However, this would misjudge the theoretical-methodological self-understanding of Walther's approach. It goes without saying, as Walther shows in her main work, that the phenomenological method aimed at general validity can also be applied to one's own experiences, as long as it is carried out in a technically correct manner, which is the case with Walther, despite some primarily conceptual weak points, grosso modo (cf. Feise-Mahnkopp, "Meta-transcendental realism”). This applies once again since intersubjective comparison with other mystical experiences confirms the essential (cf. on this position, which is not undisputed in professional discourse; note 77). Walther's account is therefore used not in spite of, but precisely because of, the conceptual instruments that are based on it. Chadwick's account was chosen for similar reasons: the professionally trained eye of the author makes it possible to give the personal account an exemplary character (despite the blind spots that are certainly present in part), which in turn is confirmed by the intersubjective comparison with other reports of psychotic experiences from the firstperson perspective.

32 Calcagno, Walther’s Phenomenology; Feise-Mahnkopp, "Meta-transcendental Realism."

33 Walther, Phänomenologie.

34 Walther, "Zur innenpsychischen."

35 Waldenfels, Bruchlinien, Grundmotive, "Die Anomalität."

36 Of course, the validity of the conclusions drawn is to be evaluated in relation to the degree of credibility one is prepared to give to the respective self-disclosures. Moreover, the conclusions drawn by no means claim to be of sufficient diagnostic value. Such value can only be determined with the help of multimodal procedures, and above all only on the basis of personal encounter. However, there are good reasons to treat the reports as authentic accounts, judging from overall sense of their descriptions and contexts. 
question of the possible significance of the results for the philosophy of consciousness, on the one hand, and for the treatment of psychoses (especially schizophrenic forms) on the other.

\subsection{Conceptual and analytical tools}

Terminologically, on the one hand I understand experience (Erlebnis) psychologically, as does Husserl, i.e., as the experience of an empirical ego. On the other, after replacing the natural attitude by the phenomenological attitude, I understand it epistemologically, i.e., as the reciprocity of intentional acts of the pure ego and its "ego-itical" and "non-egoitical" correlates. ${ }^{37}$ I refer to the former as "noetic" implications, and the latter as "noematic" implications. ${ }^{38}$ De facto, however, these cannot be separated; perception (in the Husserlian sense) is realized beyond fixed subject and object constellations. ${ }^{39}$

Besides the noetic-noematic implications, "attentional transformations," 40 i.e., the gradual increase or decrease in awareness of specific constellations in the field of perception, must also be taken into account (hereinafter also referred to as (de-)actualization).

In doing so, I am committed to both a transcendental and a real-ontological notion of perception (i.e., the pure ego, in addition to being pure mental acts of constitution, both constitutes psychophysical subjects transcendent to consciousness and is affected by them). With reference to Walther's Phenomenology, I will draw also on meta-transcendental realist thought, ${ }^{41}$ more precisely, on the notion of (imperfect) perception of spiritual being transcending both psychophysical being and the absoluteness of (transcendental) consciousness. ${ }^{42}$

For Walther, that experience genuinely differs - as primordial phenomenon (“Urphänomen”) - from any other experience. ${ }^{43}$

As Walther demonstrates in her main work (without using that terminology explicitly), sufficient analysis of the mystical experience must include not only eidetical and transcendental reduction, but also meta-transcendental reduction. ${ }^{44}$ In other words, analysis of its noetical-noematical implications (i.e., analysis of perception under psychophysical and transcendental conditions) reveals itself as analysis of meta-noetical and meta-noematical implications (i.e., analysis of perception under metaphysical and meta-transcendental conditions)..$^{45}$

I am equally compelled by Walther's theory of self, which she articulates with affirmative and critical reliance on Husserl and Pfänder, and which respectively builds upon reductions of personhood (foreshadowing Husserl's regional-ontological thought ${ }^{46}$ and Merleau-Ponty's chiasmatic thought ${ }^{47}$ ). Consequently, Walther regards humans as both "psychophysical" and "mental-spiritual" beings.

More precisely, she distinguishes between (1) a mental ego-center ("Ich-Zentrum") functioning, so to speak, as the steering center for any act of consciousness (which is both transcendental and meta-transcendental in nature); being intentional and self-aware, enabling all formal-intellectual and deliberate acts; and thus both corresponding to and differing from Husserl's notion of pure ego, including his comments on

37 Husserl, Logische Untersuchungen, 361-3.

38 Husserl, Ideas I, 172-81.

39 Ibid., 154-55.

40 Husserl, Ideas I, 182.

41 Walther, Phänomenologie; see also Feise-Mahnkopp, "Meta-transcendental Realism.”

42 Even if he doesn't treat it systematically, Husserl admits the possibility of this implication by noting that only an absoluteness exceeding the absoluteness of consciousness is conceivable as an answer to the question of God (cf. Husserl, Ideas I, 107). 43 Walther, Phänomenologie, 21.

44 Walther, Phänomenologie, 51, 119ff; see also Feise-Mahnkopp, "Meta-transcendental Realism."

45 Ibid.

46 Husserl, Ideen 2.

47 Merleau-Ponty, Das Sichtbare, 172-203. 
its "peculiarity;"48 (2) a psychophysical self or embedment of ego ("Selbst/Einbettung des Ichzentrums") functioning, so to speak, as an archive, containing both subjective and intersubjective experiential data; its actualization taking place through the ego-center's attentionality; (3) a psychophysical-spiritual basic essence ("Grundwesen"), its (spiritual) core nourishing transrational perception in ethical, aesthetical, and religious contexts, on the one hand and, in cooperation with the ego-center, motivating the empirical ego to become essentially oneself (in terms of Aristotelian entelechy), ${ }^{49}$ on the other.

Additionally, Walther claims its connection (not congruence of being) with a primordial spiritual source (labeled monotheistically by her as "God"), respectively divine essence (göttlicher Wesensgrund").50

The named components intermingle. Drawing on parts of Plato's and Aristotle's understanding of the soul, Walther grasps the mental ego-center and the spiritual core of basic essence as not only superior to the psychophysical self but also more real than the latter (because of their essential familiarity with the primordial spiritual source). ${ }^{51}$ In this respect, Walther's notion of two kinds of spirit - a human (menschlicher Geist) and a divine one (göttlicher Geist) ${ }^{52}$ - shows itself in the end to be Plotinistic, i.e., she distinguishes the former as an emanation of the latter. ${ }^{53}$

With Walther, I am also committed to an expanded Husserlian notion of "originär gebender Anschauung" (i.e., intuition affording something in an original way) unfolding in the mystical experience (and, accordingly, in transliminal experiences). ${ }^{54}$ Such perception is based not on rational operation, but on transrational operation in the Platonic sense. In other words, in the case of the mystical experience, it is a matter of (imperfect) meta-transcendental perception of a spiritual reason for being that exceeds both the sphere of psychophysical, i.e., impermanent, existence and the absoluteness of transcendental consciousness. ${ }^{55}$ This involves a steep demand for evidence (one which Walther herself does not make explicit, however, just as she does not subject it to critical examination).

At the end of all reductions, Walther claims that the spiritual being perceived in the mystical experience exposes itself accordingly as divine being, more precisely, as Trinitarian divine being. ${ }^{56}$ As I have shown elsewhere, however, Walther's trinitarian reading is not supported by the phenomenological method she employs, ${ }^{57}$ but her fundamental ontological one is. At least this applies if one accepts the premise that the genuinely mystical experience is revealed in the process of perception, i.e., as meta-noetic-noematic, not only as spiritual essence but also as spiritual being (even if not completely), a premise that lies in the nature of personal experience. ${ }^{58}$ As such, it cannot be examined from a third-person perspective, but can be supported or rejected from an intersubjective point of view.

Even so, only Walther's onto-epistemology (meaning that, in mystical experience, the perceiving subject is indeed affected by spiritual being, but the latter is simultaneously constituted by the perceiving subject in a meta-transcendental sense), will be used here, without specifying whether this is perception of a spiritual being in the immanent or transcendent sense.

The first variant regards matter and mind as complementary parts of one and the same secular reality ("unus mundus"), ${ }^{59}$ whereby a distinction is made not between matter and (rational) mind, but rather between matter and spirit (i.e., spirit encompassing both rationality and transrationality). I refer to that notion with terms from the semantic field of spirituality. The latter variant not (only) considers the integrity

48 Husserl, Ideas I, 105.

49 Aristotle, Über die Seele.

50 Walther, Phänomenologie, 125.

51 Ibid., 241.

52 Walther, Phänomenologie, 34.

53 Ibid., 122.

54 Husserl, Ideas I, 43; cf. Feise-Mahnkopp, “Meta-transcendental Realism.”

55 Feise-Mahnkopp, "Meta-transcendental Realism."

56 Walther, Phänomenologie, 173-81.

57 Feise-Mahnkopp, “Meta-transcendental Realism.”

58 Cf. Nagel, "What Is It" (the crucial point of this modern classic is the subjectivity of conscious experience which cannot be reproduced by another consciousness or represented via quantifying tools).

59 Walach, Beyond a Materialist, 74. 
of matter and mind (or spirit) realized in the secular realm, but also emphasizes the fundamental ontological and essential character of spirit. This view is found in classical theological discourse, ${ }^{60}$ and also, as Walther's own work makes clear, in religious phenomenology. ${ }^{61}$ I refer to the latter with terms from the semantic field of religiosity.

\section{Pathos and response}

Furthermore, an orientation toward Bernhard Waldenfels' reflections on pathos and response proves to be helpful. From a phenomenological point of view, pathical experiences, such as experiences and affections of the subject as the "underground and background from which all sensual and regulated behavior stands out,"62 are a basic trait of being human. Such experiences can be perceived as a crack, break or abyss (impression), and "force" the subject to respond (expression). ${ }^{63}$ In cases where the interplay between impression and expression is individually severely impaired, e.g., in the form of a significantly reduced or an excessive capacity for impression (which is, however, lacking in expressive possibilities), the pathic can to a certain extent take on a pathological character. ${ }^{64}$

\section{Transliminal experiences in mystical and psychopathological contexts}

In the 1918 winter of war, after a period of psychic tension, sorrows and grief characterized by a feeling of self-alienation, riding on a train back from a visit with her dying father, Walther had the strong impression of “sinking” into a dark abyss:

[...] I felt like I was sinking [...] into a dark, endless depth [...] At the same time, it seemed to me as if I was moving further and further away from everything that was dear to me [...]. I would only have liked to go on living if there was something that gave a higher, ultimate meaning to it all, something that suddenly gave the whole world a different appearance - but what could that have been?65

Factually, her attention is directed away from any specific thought, feeling or motivation as empirical ego, ${ }^{66}$ and accordingly (unspecifically) directed to an unknown "something" to rescue her. In this mental state, Walther is desperately trying not to lose her consciousness.

It was necessary to hold together with the last remnant of strength within oneself to avoid losing consciousness as well. Of course, this consciousness actually consisted only of the fact that I felt myself sinking and sinking without knowing where to go - as if I was falling through empty, infinite, starless space. ${ }^{67}$

Factually, Walther is now aware of herself as being pure ego (in the Husserlian term)/ego-center (in her own term) only. She describes the further development as follows:

60 E.g. Welte, "Fundamentaltheologie heute."

61 E.g. Przywara, Religionsphilosophie, Analogia entis.

62 Waldenfels, Bruchlinien, 3.

63 Waldenfels, Bruchlinien, "Die Anomalität.”

64 Waldenfels, “Die Anomalität,” 38ff.

65 Walther, Zum anderen Ufer, 223f. Since the quoted writings of Walther have not been translated into English (with one exception, the introduction and first chapter of Phänomenologie der Mystik, cf. Parker, "Phenomenology"), the author asked Amy Parker to provide translations of this and all following quotations.

66 Husserl, Logische Untersuchungen, 365.

67 Walther, Zum anderen Ufer, 224. 
As I was sinking, however suddenly, something was streaming towards me from a vast, infinite distance, something that permeated me with a feeling of deepest safety and security. It grew in strength, an ocean of warm love and kindness surrounded me. ${ }^{6} 8$

Walther describes the experience as both transitive (it triggers her feelings of highest security and safety) and predicative (being is perceived as love and goodness), thus expressing the reciprocity of noetic and noematic implications. The experience intensifies after a stop in Freiburg:

[...] that' $\mathrm{s}$ when it hit me even harder. Now a bright inner light streamed towards me from that immeasurable distance, surrounding me completely. ${ }^{69}$

That is, Walther, "outside of herself" in the Platonic sense, keeps a bright light before her mental eye and describes the further development as follows:

All the suffering I had ever experienced was as if it had never been [...]. I felt completely reborn and transformed. I no longer knew anything about myself and my surroundings, I only felt that warm flood of love that had absorbed me, looked only at that spiritual light that had permeated me $[. ..] .^{70}$

Enraptured out of the world and its empirical existence, completely imbued with the absolute quality of the experienced gaze (love and spirit-light), Walther feels like she has been reborn ("transformed").

In her autobiography, from which the account of this experience is taken (in her main work, Walther analyzes the experience in a more differentiated manner with regard to technical terminology), ${ }^{71}$ Walther concludes by noting that she was completely aware that the "something" by which she had been "seized" does not come from her own inner being (basic essence), but literally stems, in (its) spiritual reason for being, from "another world." 72

In other words, she refers to the noetic-noematic structure as meta-noetic-noematic. At the same time, by analogy to Husserl's concept of evidence ${ }^{73}$ Walther here refers to evidence that becomes transrationally effective (i.e., insight in the course of "adequately giving consciousness"74). Walther points out that she, who was raised as an atheist, only afterward asked herself whether what she had experienced could be identified with God, i.e., with the experience of one of his essential characteristics - "immeasurable love," "all-pervading spirit." 75 But it was only after studying medieval mysticism that Walther recognized her experience as a mystical one. ${ }^{76}$ And rightly so: the phenomenal comparison with reports by mystics from different times and cultures reveals common intersections. ${ }^{77}$

An answer to her question can only be found in her main work on the basis of systematic phenomenological investigations: the mystical experience is a "real, bodily - though imperfect - experience of God."78

The experience, referred to as transliminal in the context of this article, has both personal and professional implications for Walther. For example, she gets baptized ${ }^{79}$ and uses phenomenology to make

68 Ibid., 224-5.

69 Walther, Zum anderen Ufer, 225.

70 Ibid.

71 Walther, Phänomenologie.

72 Ibid., 226.

73 Husserl, Ideas I, 317ff.

74 Ibid., 273; see also Feise-Mahnkopp, "Meta-transcendental Realism."

75 Walther, Zum anderen Ufer, 225.

76 Ibid., 238.

77 Cf. for example Sloterdijk, Mystische Weltliteratur. This assessment, which is directed at the characteristic experience, is valid despite the time- and culture-dependent differences that become apparent with regard to philosophical-theological interpretations of the experience. On these two poles cf. for example Fenton, "Mystical Experience” and Rothberg, "Contemporary Epistemology.”

78 Walther, Phänomenologie, 22; see for a critical appraisal of Walther’s approach, including meta-methodological criticism, Feise-Mahnkopp, "Meta-transcendental Realism.”

79 Walther, Zum anderen Ufer, 636. 
personal experience universally understandable. Since she writes in her autobiography in a way that suggests that she would like to pass on to other people the inspiration she experienced in her mystical experience, ${ }^{80}$ there is a further correspondence here to Plato.

Peter Chadwick's account of personal experiences in the context of an incipient psychosis in the category of schizophrenia begins with reminiscences of psychic miserableness and self-contempt that match Walther's description of personal troubles and self-alienation in principle, if not in gradation. (Chadwick's account is much more intense than Walther's; we will come back to this point in the subsequent section.)

After resigning a post as university lecturer in psychology in summer 1979, Chadwick "hit the base of (his) fortune." ${ }^{81}$ After "being essentially alone, penniless, [...] felt scorned, hated, and with no future now and a horrific past," as Chadwick puts it, the following perception occurred:

[...] it was as if a portal opened and I was overwhelmed by a positive, euphoric, spiritual experience. It was like being an empty vessel being filled with the Divine Light of God. The transgressions of my many persecutors quickly became trivial. Hate turned to love, anger and revenge wishes turned to forgiveness. [...] the tortuous agonies of my past were forgotten. I was as if reborn with a new self-perception and a new purpose, to bring God in the world..$^{82}$

Similar to Walther, Chadwick's experience is also spontaneous. More precisely, as with Walther, it is characterized by a gradual weakening that develops into a de-actualization of all perceptual references concerning the empirical ego and its anchoring in the area of psychophysical existence - self and basic essence. ${ }^{83} \mathrm{As}$ a consequence, a state of pure ego-consciousness occurs. But where Walther speaks of a "dark abyss" to describe this state metaphorically, Chadwick uses the metaphor of an "empty vessel." There are also phenomenal intersections in the descriptions of the core event. Similar to Walther, Chadwick describes the process as passive-enthusiastic: with the image of the "vessel," he expresses how completely he was seized by what he describes noetically-noematically - again just like Walther - as being both lovingly and benevolently acting as well as a being of light and love.

Similar to Walther, it seems to be a matter of "being outside oneself" in the Platonic sense, which favors the transrational leap into eidetic perception. As well, Chadwick speaks of a (euphoric) purely spiritual perception of light. This means that here, just as with Walther, meta-noetic or meta-noematic implications come into play. Furthermore, as with Walther, a high, possibly even higher, degree of evidence is expressed, because Chadwick explicitly describes the experience as "Divine." 84

Finally, in Chadwick's description a Platonic-transformative implication also becomes effective. Similar to Walther, he speaks of "rebirth" and of a new dimension of meaning or aim of life: to carry the God experience into the worldly context.

\subsection{Structural analytical perspective}

With the help of Walther's theory of self, the experiences can be structurally described analytically. Using her terminology, we can identify the following steps in both accounts:

(a) The Empirical ego is being reduced to pure ego/ego-center (=de-coupling from self and basic essence).

80 Ibid., 226.

81 Chadwick, “On Not Drinking,” 67.

82 Ibid.

83 At the same time, there is evidence to suggest that Chadwick's leap from the empirical to the pure ego is not made with a purity comparable to Walther's, which may be due to the fact that through her phenomenological training Walther's consciousness makes such a leap more easily.

84 This also applies, of course, to Walther's account, and it must be critically taken into account that it is not (any longer) clear whether this valuation occurred immediately or was only formed in retrospect (i.e. with the help of an even more pronounced re-inflection process). (On the fundamentally re-flexive character of every perception, cf. Husserl, Ideas I, 142-5.) 
(b) The Ego-center is only aware of itself (=pure ego-consciousness).

(c) The Ego-center's attention is being (passively) captured by spiritual being and is (actively) holding its attention to it (=perceiving it as both familiar with and other to itself).

In other words, we are dealing with a decoupling of ego-center, self (in terms of an embedment of egocenter), and basic essence in consciousness. More precisely, it is a de-actualization of all personal or natural-worldly implications in the field of perception. Consequently, pure self-consciousness prevails.

As a decisive attentional change, the increasing constitution of an essentially spiritual noema has to be mentioned, which in the meta-transcendental perceptual process of ego-center is paradoxically recognized both as related to and different from itself.

As explained above, in order to do justice to the experience as such, it cannot be determined here whether the experience is about a difference that becomes effective in the immanent sense (i.e., perception of a component of mental-spiritual reality in the sense of the "unus mundus" model) or about a difference that becomes effective in the transcendent sense (i.e., perception of a metaphysical reason of being, in which the human spirit emanatively has a share but which at the same time exceeds it in a fundamental way).

\section{The experience in the light of responsive phenomenology}

Referring to Waldenfels' terminology, we can also say that both Walther and Chadwick had a distinctly pathical experience (impression), one that forces them both to an existential response (expression). I next discuss whether, and to what extent, they find appropriate answers to their lived experience.

\subsection{Intermediate result}

To summarize at this stage: On a phenomenal level, no essential differences between the mystical and the initial sequence of psychotic experience are to be found. However, the situation is different if we integrate the psychic implications before and after the transliminal experience into the comparison.

\subsection{Psychodynamic terminology and analysis tools}

Psychoses of the schizophrenic spectrum of disorders are described in textbooks as multifactorial, i.e., as bio-psycho-social events. ${ }^{85}$ In this context, the "vulnerability stress" model is of particular importance, i.e., the assumption that response to experience varies as a result of genetic disposition. ${ }^{86}$ From this point of view - which is essentially physical material and, with all its constructivist implications, ultimately deterministic - other connections essential for the understanding of non-organic psychoses remain invisible.

This includes insight into the functionality of mental dysfunctionality. In other words, (non-organic) psychotic symptoms are not "disorders" or pathological, deficiency-related phenomena, but rather fulfill a defensive, protective or compensatory function. ${ }^{87}$ Or yet again, they are to be understood as autopoietic attempts by the psyche to compensate subjectively for experiences perceived as extremely pathic. These

85 Cf., for example, Gaebel and Zielasek, “Ätiopathogenetische Konzepte,” 98-9.

86 Ibid., 106-7.

87 Mentzos, “Schöpferische Aspekte," 13. Dissociative components (as we find in both Walther's and in Chadwick's accounts) indicate the psyche's attempt to withdraw from experiences which are traumatic, i.e., too demanding. 
attempts are inherent in a formative dimension (in the fictitious sense), which must be taken into account in the therapeutic context.

This also includes, precisely, the role that spiritual components play in the development or dynamization of non-organic psychoses, on the one hand, and in the treatment context, on the other. ${ }^{88}$

Against this background, the symptomatology of the prodromal stage of schizophrenia, i.e., a sudden interest in religious-spiritual topics, ${ }^{89}$ should be seen not as an indicator of pathologicality, but rather as a sign that the structural context of the psyche is reactively in such a state of dissolution that it is (expressed platonically) closer to "divine madness" than is the case in ordinary everyday consciousness, or (phenomenologically speaking) has a higher affinity to transrational actualizations.

The case studies of Williams from the field of recovery research make it clear that the key to healing is not the medically induced premature interruption of this process, but rather its professional support in the protected therapy room (together with subsequent psychotherapeutic work). ${ }^{90}$

Empirically comprehensible connections like these can be explained with reference to the ancient Greek teachings on the soul, in particular - besides Platonic thought - the Aristotelian concept of entelechy, whereby the soul strives to update its own potential. ${ }^{91}$ This also applies if there are obstacles to such actualization in the concrete bio-psycho-social interplay. Notably, this assumption can also be found in humanistic psychology. ${ }^{92}$

Following the phenomenological reception of entelechy, the realization of the potential of the personal self is to be understood not only psychophysically and mentally, but also (and especially) spiritually. ${ }^{93}$ Even if Walther's concept of a spiritual core potential of personality that urges actualization cannot be sufficiently understood without its connection to a metaphysical - divine - reason for being, ${ }^{94}$ an immanent reading can be considered equally possible. ${ }^{95}$

Regardless of the ontological classification of the spiritual dimension, however, it is necessary to take it into consideration adequately in the context of both origin and treatment.

Following Walther on this point, ego-center, self, and basic essence are separated in the execution of consciousness. The transformation carried out in the encounter with the (divinely) spiritual reason for being (which acts as a living and at the same time revitalizing one), ${ }^{96}$ can only become therapeutically effective after the experience of personal wholeness (self and basic essence) can be restored via ego-consciousness (i.e., ego-center) (both expanded and transformed through the transliminal experience).

Since in people diagnosed with schizophrenia a fragmentation of personal wholeness has often begun or occurred much earlier (whether as a consequence of individual reactions to specific experiences or substance abuse) ${ }^{97}$ - the classic "schizophrenic" symptomatology, i.e., disorders in the context of thinking, feeling, and behavior, ${ }^{98}$ refers to this circumstance - a restoration of personal wholeness after the transliminal experience is difficult in a double sense. ${ }^{99}$

88 Williams, Rethinking Madness; Clarke, "Psychosis.” In reference to this, talk of the bio-psycho-socio-spiritual implications is preferable to that of the bio-psycho-social implications (cf. Freund, “...denn ich trage,” 58, with reference to Hefti and Unterrainer).

89 Falkai et al., "Schizophrene Psychosen," 1602.

90 Healing means the adequate integration of the experience into the self-concept and the further lifestyle of the person affected, not the restoration of a status quo ante. To what extent this radically process-oriented view is justified should be investigated by further research.

91 Aristotle, Über die Seele, 173.

92 Rogers, Der neue Mensch.

93 See, for example, Pfänder, "Psychologie der Gesinnungen I, II;” Conrad-Martius, Metaphysische Gespräche.

94 A comparable approach can be found, for example, in Stein, Endliches und ewiges.

95 The former is represented, for example, by Maslow, Motivation; the latter by Frankl, Der leidende Mensch.

96 Walther, Phänomenologie, 156; cf. also Williams, Rethinking, 263.

97 Falkai et al., "Schizophrene Psychosen," 1597.

98 Ibid., 1601-4.

99 Williams points out that the use of psychotropic drugs makes the autopoietic mental process of producing equilibrium virtually impossible (Rethinking). 
In other words, the transliminal experience is not processed by a personality that is able to confidently combine self and basic essence with the help of its ego-center, but rather, depending on the individual disposition, it is either emotionally split off (reified) or mentalized in an exaggerated, i.e., delusional, way (hyper-reflexicized). A lack of self-esteem, for instance, can be reinterpreted as being chosen by "divine" power in the face of the spiritual reason for being. If the lack of self-esteem is not stopped therapeutically, in case of a further dynamization, e.g., by self-hatred, a polar reversal can occur: in the face of the spiritual reason for being, enthusiasm is attributed to diabolical power.

\section{Psychodynamic implications of transliminal experiences}

In Walther's case, a profound holistic exhaustion as a result of stress, personal sorrows, and grief precedes the experience of dissolution of boundaries: "[...] all my mental, spiritual and physical powers were used up. I felt like a completely burnt down candle [...]."100

This manifests itself through dissociation of the (otherwise connected) physical, mental, and spiritual reference levels of personal self-perception:

\footnotetext{
Everything that surrounded me became strangely distant and indifferent to me [...]. Sometimes I was filled with a strange inner tension as if I had to hold myself together with all my strength in order not to fall apart as if I could no longer hold my thoughts [...]. When this state - fluctuating between dissociation and de-realization - becomes more acute, “[...] it was as if I was sinking inwardly into a dark, endless depth in which there was no hold or light anywhere. At the same time, it seemed to me that I was moving away more and more from everything I had loved and valued [...]. ${ }^{101}$
}

This intensification, according to Walther, would have resulted in madness if something had not been found that "gave everything a higher, final meaning." But before that happens, Walther's ego-consciousness is drawn into a kind of tunnel: "[...] I felt how I was sinking and sank without knowing where I was going - as if I was plunging through empty, infinite, starless space.” ${ }^{102}$

Decoupled from the self, the ego-center is nevertheless able to remain with itself - "[...] it was necessary not to dissolve me senselessly" - and experiences a new hold from the primordial source of divinity "[...] something was streaming towards me from a vast, infinite distance, something that permeated me with a feeling of deepest safety and security." 103

As mentioned above, this experience changes Walther's professional and personal existence fundamentally: from this point on, not only is she predominantly engaged with border phenomena, observing and training her own spirituality, but the former atheist is also baptized according to Catholic rites.

Retrospectively, Walther not only classifies the experience as a mystical experience, but also recognizes that she has followed the path of mystical training beforehand, without knowing it. (Among other things, she has learned through strokes of fate not to adhere to material things or persons and was, as a trained phenomenologist, familiar with conscious variation. $)^{104}$

As the trigger for the transliminal experience, she blames a brief disconnection of her ego-center from its embedment/self as a result of her distress at the time, and emphasizes that the ego-center succeeds in establishing a connection with basic essence or the primordial source of divinity. Walther also states that her psychophysical-spiritual organism is energized by what she has experienced. In other words, Walther's transliminal experience contributes significantly to strengthening her personal and professional identity (i.e., the relationship between impression and expression appears balanced).

100 Walther, Zum anderen Ufer, 223.

101 Ibid. 224.

102 Walther, Zum anderen Ufer, 224.

103 Ibid.

104 Walther, Zum anderen Ufer, 224. 
Chadwick's case is different. There are some comparable aspects, such as the occurrence of a psychical crisis immediately before his transliminal experience:

In 1979 [...], I felt battered by the hatred and gossip of the world [...]. In the summer [...], having resigned a university lecturing post in psychology because of increasing paranoia, I hit the base of my fortunes. Living in a bedsitter in Hackney, I was essentially alone, penniless, unemployed, felt scorned, hated, with no future now and a horrific past, it was as if a portal opened and I was overwhelmed by a positive, euphoric, spiritual experience. ${ }^{105}$

But Chadwick's crisis is more pronounced than Walther's, corresponding to years of psychic instability. More precisely, the psychologist points to poorly developed self-esteem or a weakness of the self, resulting from the devaluation of his person and sexual orientation (due to his parents' house and environment ${ }^{106}$ ). The time at which psychosis sets in is marked by the culmination of his self-doubt and the loss of all material and professional security. Also, feelings of hatred against his tormentors become noticeable (but are kept in check by paranoia). ${ }^{107}$

Unlike Walther, Chadwick's transliminal experience does not lead him directly to a strengthening of his personality. Instead, the psychic instability that favors transliminal experience leads to the formation of an insane system in which he interprets what he has experienced (self-increasingly) as a consequence of being chosen by God, but in the further course of psychosis translates this interpretation into the (self-loathing) assumption that he was personally commissioned by the Prince of Hell. He experiences the turnaround as follows:

In this state of mind, what previously had been mystical thoughts such as 'All is Meaning' now became psychotic thoughts such as 'Everything means something, even street signs, advertisements, etc.' What previously had been 'The cosmos is an interconnected unity' now became 'Everyone and everything is against me.' 108

From the acute psychosis in which - obeying "voices" - he throws himself in front of a bus, Chadwick seeks the help of psychotropic drugs; he succeeds in averting a relapse without medication and by banishing the "demonic" forces, i.e., impulses of self-loathing, with the help of "divine" forces, i.e., self-respecting impulses, experienced in the prodromal stage. (In this respect, the relationship between impression and expression appears anything but balanced.)

Only after the residual phase does he begin to integrate the transliminal experiences that occur during psychosis, in particular the therapeutic effect of oppressing its positive effects, into his personal and professional activities.

It should be noted that in both cases the transliminal experience was preceded by a personal crisis. Walther not only masters this faster than Chadwick due to (a presumably) higher ego-stability (or stronger resilience), ${ }^{109}$ but also uses the forces released in the process directly to further consolidate her personality. Chadwick is initially at the mercy of the dynamics of the crisis, which include transrational actualizations. Only when he specifically falls back on the spiritual resources, i.e., coupling ego-center and basic essence, and combines these with psychotherapeutic procedures that strengthen his self-image - in other words, balancing self and basic essence consciously by ego-center - does he succeed in strengthening his egostability, a state that remains endangered due to his vulnerable psyche.

These events can be better understood through Walther's deepening understanding of the "internal psychic structure of schizophrenia." ${ }^{110}$

105 Chadwick, "On not drinking," 67.

106 Ibid.

107 Chadwick, "On not drinking," 68.

108 Ibid., 69.

109 For its terminology and psychological implications (here in the context of children development) see Masten, "Ordinary Magic."

110 Walther, "Zur innenpsychischen.” 


\section{Walther's reflections on the psychic structure of schizophrenia}

Walther (like Bleuler) ${ }^{111}$ blames a disturbance of the ego-center for the development of symptoms that belong to the schizophrenic clinical picture. This manifests itself primarily in two ways: First, the connection to the self is cut off (typical symptoms are perception and affect disorders), which means that the egocenter is no longer able to actualize perceptions and feelings from its embedment/self. Second, it has lost its filter function; in this case feelings and thoughts flow disordered into consciousness (typical symptoms are loosening of associations, withdrawal of thoughts and dispersion of thoughts). As a "side effect" of this de-coupling of self and ego-center, Walther sees the possibility of an increased perceptiveness with regard to basic essence according to its connection with the primordial source of divinity (with which she explains, en passant, the emergence of religious interests in the prodromal stage of schizophrenia). ${ }^{112}$

If the ego-center is not intact, Walther continues, even the contents of consciousness associated with basic essence and basic essence's connection to divine essence cannot be coherently updated or brought into equilibrium with impulses from the self. The result is the formation of delusional systems.

Walther's explanation for the "hearing of voices" so typical in the context of schizophrenic experience is worth considering. Resorting to Pfänder's idea of "Nebenwirklichkeit" ("side-reality"), i.e., the constant, inwardly turned self-awareness of ego, she proposes to read voice-hearing as the separation of side-reality, i.e., as fractals of the ego (a symptom of this is the commentary style of thinking, e.g., "Now he puts down the knife," "now she goes out of the room")..113 According to Walther, those that convey negative, i.e., insulting and contemptuous, contents (e.g., "Now the son of a bitch puts down the knife," "Now the piece of dirt leaves the room") are a special way of playing with the sound of thoughts or hearing voices.

Although she articulates the structural mechanism that is likely involved - it is a matter of emotions (from the self) that "would not cross the threshold of consciousness in the normal life of the soul through a kind of pre-control of the ego" - she does not draw the obvious consequence that the structural scheme of ego-center, self, and basic essence overemphasizes the conscious and unconscious implications of the life of the soul (in the sense of actualization and latency), without considering the realm of the subconscious in the Freudian sense. ${ }^{114}$

\section{Understanding Chadwick's experience through Walther}

Chadwick's case can be coherently explained by Walther's structural consideration. Chadwick's ego-center does not update data in its embedment/self sufficiently or at all. The de-coupling from the self makes room for data from basic essence and enables the encounter with the primordial source of divinity (i.e., transliminal experience).

Since the ego-center is impaired in its function (and is not therapeutically counteracted), further updates of data from basic essence corresponding to the primordial source of divinity are not coherent; as a consequence, the transliminal experience gets incorporated into the delusional system. ${ }^{115}$

In the further course of the process, the sounds of thought or "hearing voices" are added, on the one hand characterized by splitting off in the ego-center (fractals of side-reality), and on the other by the absent

111 Bleuler, Dementia praecox.

112 Walther, "Zur innenpsychischen."

113 Ibid.

114 The therapeutic necessity of introducing psychoanalytic procedures into the treatment of schizophrenia was, as the last sentence of the article shows, evident to her, but not the necessity of incorporating the subconscious into her scheme of consciousness.

115 This mechanism is also articulated in more recent research (particularly on ecclesiomorphic neurosis), cf. Meissner, "The phenomenology.” Pfeifer describes it as follows (translated from German by the author): "Neurosis as vehicle, that can be used [...] by religion” (Pfeifer, "Religiöse Ängste,” 148). 
control function of the ego-center with regard to the updating of previously suppressed experience contents (as far as the psychoanalytical supplementation is concerned). The psychotic decay is halted by the fact that the ego-center is coupled with basic essence, and this coupling is placed in the service of an equally weighted relationship between self and basic essence mediated by the ego-center.

This equilibrium, Walther continues, is the decisive criterion for distinguishing psychotic from mystical, or delusional from genuinely religious, experience. In other words, even if the system temporarily cuts off its conscious contact with empirical reality and thereby disconnects itself temporarily from both the egocenter's embedment/self and its basic essence, i.e., is at first pure ego-consciousness and then an egoconsciousness expanded and transformed by the divine essence, it succeeds in integrating the mystical experience into a stable self- and (super-)world-relationship - in contrast to many patients with schizophrenia diagnoses, who have partially identical experiences during the psychotic process, but who cannot integrate these experiences into a stable equilibrium between ego-center, self, and basic essence during the psychotic process.

Against this background, the therapeutic aim is to achieve an equilibrium of self and basic essence mediated by the spiritually transformed ego-center.

\section{Response to the leading research question}

Neither the mystical experience nor the phenomenally identical experiential implications of psychoses in the category of schizophrenia are pathological. In both cases, enthusiasm and ego-consciousness as well as expanding and transforming implications come into play.

If, however, as in Chadwick's case, there is an impaired psyche (i.e., disconnection of ego-center, self, and basic essence) experiencing the transliminal experience, and if this psyche does not succeed in further progressing in (therapeutically) absorbing this impairment, the experienced dissolution of boundaries can be integrated into the delusional system, which functions as compensation for the conflicts underlying the psychotic disintegration. In this case, and only in this case, we have to speak of "pathological" experience. ${ }^{116}$

\section{Philosophical significance}

These experiences, examined here phenomenologically in a mystical and psychotic context, have philosophical implications.

Analogous to the considerations Wouter Kusters made in his Philosophy of Madness ${ }^{117}$ with regard to the proto-philosophical significance of his psychotic experiences for transcendental philosophy - Kusters focusing here primarily on hyper-reflexive states of consciousness, which gave him "crystalline" insights ${ }^{118}$ - I would like to conclude with a discussion of the proto-philosophical significance for a meta-transcendental philosophy of the phenomenology of mysticism and the phenomenology of psychotic experience of people diagnosed with schizophrenia.

If we take seriously the reports of mystics and those of people with a schizophrenia diagnosis who witness comparable transliminal implications, we have two possibilities: on the one hand, we can understand the experiences in question as immanent (spiritual) experiences, in other words, as (secular)

116 In terms of an intensification of the pathic-responsive interplay between human being(s), nature and world (described by Bernhard Waldenfels).

117 Kusters, Filosofie van de Waanzin.

118 Kusters, "Radical turns." 
experiences of transrational consciousness. On the other hand, we can understand the experiences in question as transcendent (spiritual) experience, ${ }^{119}$ i.e., as a partial encounter with an absolute spiritual being transcending both (human) consciousness, world and nature, which is classically referred to with terms like God, but to which this view cannot be reduced.

Walther advocates such a view, pointing out that the noetic-noematic implications of mystical experience indicate a genuineness on phenomenal grounds that makes imperative the realization of an absolute (spiritual) being beyond the absoluteness of (transcendental) consciousness. ${ }^{120}$ With this view she takes up Husserl's idea that the question of God could only be answered in the sense of an "absoluteness in a fundamentally different sense than the absoluteness of the consciousness." ${ }^{121}$ Chadwick, too, describes his transliminal experiences in the context of the psychotic process as "Divine."

However, regardless of the question of whether the transliminal experiences under consideration here should be understood as spiritual experiences in the immanent or transcendent sense, the connections pointed out here deserve to be taken seriously in that they suggest a basic distinction between mind and spirit, which corresponds to the distinction between transcendentality and meta-transcendentality. Of course, this distinction should be examined and sharpened with the help of further research.

Walther's systematic phenomenological analyses as well as the conceptual tools based on them can contribute to the acquisition of a differentiated understanding of mind and consciousness. Moreover, integrative consciousness research ${ }^{122}$ can benefit from these both epistemologically and ontologically. At the same time, the phenomenological method practiced by Walther (which I have used in the comparison made here) can contribute to further establish the phenomenological turn that can be currently observed in consciousness research. ${ }^{123}$

\section{Psychotherapeutic consequences}

As mentioned above, psychotherapeutic consequences also arise from the experiential contexts described here. In addressing experiences such as those reported by Walther and Chadwick, it should be noted that our bio-psycho-social understanding of the development, course, and treatment of schizophrenic psychoses needs to be supplemented by a further factor, the spiritual one. ${ }^{124}$ Concepts such as Walther's (drawing on Pfänder) that, in addition to psychophysical and mental implications, consider spiritual implications to be essential for personality development as well (i.e., representing an idea of man beyond the Cartesian dualism of matter and mind), also benefit more recent phenomenologically informed findings, which regard this same dualism not only as a humanity-damaging constituent of modernity, but also as a constituent of schizophrenic experience. ${ }^{125}$

In therapeutic terms, this generally means that spiritual components must be incorporated into the therapeutic process. In this respect, Plato's reflections on the possibilities of "divine" madness to cure pathological forms of madness (which may often appear to us today as outdated) prove to be surprisingly connectable to advanced psychotherapeutic practice and research. ${ }^{126}$ The discourse of the pathical, in reference to the insights into fundamental modes of pathos and response articulated by Waldenfels and

119 A comparison with the phenomenology of the sacred, as Rudolf Otto achieves in his classical work on the sacred, reveals many similarities, as I show elsewhere (Feise-Mahnkopp, “Das Heilige erleben”).

120 Walther, Phänomenologie; cf. also Feise-Mahnkopp, "Meta-transcendental Realism.”

121 Husserl, Ideas I, 107.

122 That is, research on consciousness combining physical and psycho-mental (as well as spiritual) implications of mind.

Cf. Walach, Beyond a Materialist, 69.

123 Ibid., 86.

124 See also Hefti, “Spiritualität."

125 Sass, Madness and Modernism, cf. in the anthropological context also Fuchs, Die Verteidigung des Menschen.

126 See, for example, Utsch et al., Psychotherapie und Spiritualität. 
others, does not mean psychopathology in the sense of a counterpart to mental health, but rather psychopathology in the sense of an understatement or exaggeration of the fundamental structural and functional relationships of human consciousness (including psychophysical, rational, and transrational implications).

For people diagnosed with schizophrenia it means, in concrete terms, that they should consciously integrate their transliminal experiences into the psychotherapeutic work, in which an equilibrium between the transliminal, extended ego-center, its embedment/self and basic essence should be an overriding therapeutic goal.

\section{Outlook}

To conclude, transliminal experiences belong exclusively to neither the mystical (i.e., religious) sphere nor the psychotic context. Rather, they belong to the fundamentally possible sphere of human experience.

In this respect, they challenge our current philosophical assumptions and thus provide a reason for further research.

Moreover, according to the connections shown here, they contain salutogenic potential from which every personality development can benefit, especially the development-oriented psychotherapy of people diagnosed with schizophrenia. In this respect, they not only challenge established psychotherapeutic practices, but once again make further research indispensable.

\section{References}

Aristotle. Über die Seele. Greek/German, edited and translated by Gernot Krapinger. Stuttgart: Reclam, 2011.

Aten, Jamie, O’Grady, Kari, and Worthington, Everett (eds.) The Psychology of Religion and Spirituality for Clinicians. New York: Routledge, 2012.

Bleuler, Egon. Dementia Praecox, Oder Gruppe der Schizophrenien. Leipzig: Deuticke, 1911.

Bonelli, Raphael M. "Das psychotherapeutische Unbehagen mit der Religion." In Spiritualisierung oder Psychologisierung? Deutung und Behandlung außergewöhnlicher religiöser Erfahrungen, edited by Henning Freund and Samuel Pfeifer, 47-52. Stuttgart: Kohlhammer, 2019.

Calcagno, Antonio (ed.) Gerda Walther's Phenomenology of Sociality, Psychology, and Religion. Cham: Springer Nature Switzerland AG, 2018.

Chadwick, Peter. “'On Not Drinking Soup with a Fork’: From Spiritual Experience to Madness to Growth - A Personal Journey.” In Psychosis and Spirituality. Consolidating the New Paradigm, edited by Isabel Clarke, 65-75. Oxford: WileyBlackwell, 2010.

Claridge, Gordon. "Spiritual Experience: Healthy Psychoticism?” In Psychosis and Spirituality. Consolidating the New Paradigm, edited by Isabel Clarke, 75-89. Oxford: Wiley-Blackwell, 2010.

Clarke, Isabel. "Psychosis and Spirituality: The Discontinuity Model." In Psychosis and Spirituality. Consolidating the New Paradigm, edited by Isabel Clarke, 101-15. Oxford: Wiley-Blackwell, 2010.

Conrad-Martius, Hedwig. Metaphysische Gespräche. Halle: Niemeyer, 1921.

Falkai, Peter, Schennach, Rebecca, Lincoln, Tania, Schaub, Annette, and Hasan, Alkomiet. "Schizophrene Psychosen." In Psychiatrie, Psychosomatik, Psychotherapie, edited by Hans-Jürgen Möller, Gerd Laux and Hans-Peter Kapfhammer, 1583-675. Vol. 3. Heidelberg: Springer, 2017.

Feise-Mahnkopp, Patricia. “Das Heilige erleben und deuten: Potentiale für Psychotherapie und Seelsorge.” Magazin für Psychotherapie und Seelsorge (Themenheft "Heilig") 4 (2020), 34-7.

Feise-Mahnkopp, Patricia. "Meta-transcendental Realism in Gerda Walther’s Phenomenology of Mysticism. A Critical Appreciation with Particular Reference to Post-materialist Notions of Mind, Being, and Self." In Analecta Husserliana (The Yearbook of Phenomenological Research), edited by William S. Smith, Jadwiga S. Smith and Daniela Verducci. Springer, 2021, forthcoming.

Fenton, J. Y. “Mystical Experience as a Bridge for Cross-Cultural Philosophy of Religion.” In Religious Pluralism and Truth: Essays on Cross-cultural Philosophy of Religion, edited by T. Dean, 189-204. Albany, NY: SUNY Press, 1995.

Frankl, Viktor. Der leidende Mensch. Anthropologische Grundlagen der Psychotherapie. Bern: Huber, 1984.

Freud, Sigmund. "Zwangshandlungen und Religionsübungen.” In Collected Works, Vol. VII. Frankfurt a. M.: Fischer, 1993. 
Freund, Henning. “'...denn ich trage die Malzeichen Jesu an meinem Leibe.' Stigmatisation als bio-psycho-sozio-spirituelles Geschehen.” In Spiritualisierung oder Psychologisierung? Deutung und Behandlung außergewöhnlicher religiöser Erfahrungen, edited by Henning Freud and Samuel Pfeifer, 51-69. Stuttgart: Kohlhammer, 2019.

Fuchs, Thomas. Die Verteidigung des Menschen. Frankfurt am Main: Suhrkamp, 2020.

Gaebel, Wolfgang and Zielasek, Jürgen. “Ätiopathogenetische Konzepte und Krankheitsmodelle in der Psychiatrie.” In Psychiatrie, Psychosomatik, Psychotherapie, edited by Hans-Jürgen Möller, Gerd Laux and Hans-Peter Kapfhammer, 95-123. Vol. 1. Heidelberg: Springer, 2017.

Hefti, René. "Spiritualität - die vierte Dimension oder der vergessene Faktor im biopsychosozialen Modell." Primary Care 10 (2010), 259-60.

Husserl, Edmund. In Ideen zu einer reinen Phänomenologie und phänomenologischen Philosophie. Zweites Buch.

Phänomenologische Untersuchungen zur Konstitution, edited by Marly Biemel. Den Haag: Nijhoff, 1952 (HuA IV).

Husserl, Edmund. Logische Untersuchungen. Hamburg: Felix Meiner, 2009 (identical with Hua XVIII, XIX/1-2).

Husserl, Edmund. Ideas I. Ideas for a Pure Phenomenology and Phenomenological Philosophy, translated by Daniel 0. Dahlstrom. Book 1. Indianapolis: Hackett Publishing, 2014.

James, William. “The Varieties of Religious Experience.” In Writings 1902-1910, edited by Bruce Kucklik. New York: Literary Classics of the United States, 1987.

Jaspers, Karl. Allgemeine Psychopathologie. Berlin, Heidelberg, New York: Springer, 1973.

Kusters, Wouter. Filosofie van de Waanzin. Rotterdam: Lemniscaat, 2014.

Kusters, Wouter. "Radical Turns in the Natural Attitude to Life." Philosophy, Psychiatry, and Psychology 23:2 (2016), 129-46.

Maslow, Abraham. Motivation and Personality. New York: Harper \& Row, 1970.

Masten, Ann S. “Ordinary Magic. Resilience Processes in Development.” American Psychologist 56:3 (2001), 227-38.

Meissner, W. W. “The Phenomenology of Religious Psychopathology.” Bull Menninger Clin 55 (1991), 281-98.

Mentzos, Stavros. Lehrbuch der Psychodynamik. Die Funktion der Dysfunktionalität psychischer Störungen. Göttingen: Vandehoeck \& Ruprecht, 2011.

Mentzos, Stavros. "Schöpferische Aspekte der psychotischen Symptomatik, Vergleichbare ästhetische Qualitäten im Traum und in der Psychose." In Das Schöpferische in der Psychose, edited by Stavros Mentzos and Alois Münch, 13-27. Göttingen: Vandenhoeck \& Ruprecht, 2012.

Merleau-Ponty, Maurice. Das Sichtbare und das Unsichtbare. Gefolgt von Arbeitsnotizen. München: Fink, 2014.

Nagel, Thomas. "What Is It Like to Be a Bat?" The Philosophical Review 83:4 (1974), 435-50.

Oehler, Klaus. Lehre vom Noetischen und Dianoetischen Denken bei Platon und Aristoteles. Ein Beitrag zur Erforschung der Geschichte des Bewußtseinsproblems in der Antike. Hamburg: Felix Meiner, 1985.

Pargament, Kenneth I. Spiritually Integrated Psychotheraphy. Understanding and Adressing the Sacred. New York: Guilford, 2007.

Pargament, Kenneth I. (ed.) APA Handbook of Psychology, Religion and Spirituality. Washington: American Psychological Association, 2013.

Parker, Rodney K. B. “Phenomenology of Mysticism. Introduction and Chapter One.” In Gerda Walther's Phenomenology of Sociality, Psychology, and Religion, edited by Antonio Calcagno, 115-35. Cham: Springer Nature Switzerland AG, 2018.

Pfänder, Alexander. "Psychologie der Gesinnungen." In Jahrbuch für Philosophie und phänomenologische Forschung (I), 325-404. Halle: Max Niemeyer, 1913.

Pfänder, Alexander. "Psychologie der Gesinnungen.” In Jahrbuch für Philosophie und phänomenologische Forschung (III), 1-125. Halle: Max Niemeyer, 1916.

Pfeifer, Samuel. "Religiöse Ängste und Neurosen.” In Psychotherapie und Spiritualität. Mit existentiellen Konflikten und Transzendenzerfahrungen professionell umgehen, edited by Michael Utsch, Raphael M. Bonelli and Samuel Pfeifer, 143-50. Heidelberg: Springer, 2014.

Plato. "Phaidros." In Sämtliche Werke, edited by Burghard König, translated by Friedrich Schleiermacher, 539-611. Vol. 2. Reinbek bei Hamburg: Rowohlt, 1994.

Przywara, Erich. Religionsphilosophie katholischer Theologie. München: Oldenbourg, 1927.

Przywara, Erich. Analogia Entis. Metaphysik. Vol. 1. München: Kösel/Pustet, 1933.

Rogers, Carl R. Der neue Mensch. Stuttgart: Klett-Cotta, 1981.

Rothberg, Daniel. “Contemporary Epistemology and the Study of Mysticism.” In The Problem of Pure Consciousness: Mysticism and Philosophy, edited by Robert K. C. Forman, 163-210. New York: Oxford University Press, 1990.

Sass, Louis A. Madness and Modernism. Insanity in the Light of Modern Art, Literature and Thought. New York: BasicBooks, 1992.

Sloterdijk, Peter (ed.) Mystische Weltliteratur. Collected by Martin Buber. München: Diederichs, 2007.

Sperry, Len, and Shafranske, Edward P. (eds.) Spiritually Oriented Psychotherapy. Washington: APA, 2005.

Stein, Edith. Endliches und ewiges Sein. Versuch eines Aufstiegs zum Sinn des Seins. Freiburg: Herder, 1986.

Strassberg, Daniel. Der Wahnsinn der Philosophie. Verrückte Vernunft von Platon bis Deleuze. Zürich: Chronos, 2014.

Thalbourne, Michael A., Bartemucci, L., and Delin, P. S. "Transliminality: Its Nature and Correlates." The Journal of Parapsychology 58 (1997), 3-38. 
Utsch, Michael, Bonelli, Raphael M., and Pfeifer, Samuel (eds.) Psychotherapie und Spiritualität. Mit existentiellen Konflikten und Transzendenzerfahrungen professionell umgehen. Heidelberg: Springer, 2014.

Utsch, Michael. "Religiosität und Spiritualität in den Psychotherapeutischen Schulen." In Psychotherapie und Spiritualität. Mit existentiellen Konflikten und Transzendenzerfahrungen professionell umgehen, edited by Michael Utsch, Raphael M. Bonelli and Samuel Pfeifer, 67-85. Heidelberg: Springer, 2014.

Utsch, Michael. "Religionspsychologische Erklärungen für außergewöhnliche Erfahrungen.” In Spiritualisierung oder Psychologisierung? Deutung und Behandlung außergewöhnlicher religiöser Erfahrungen, edited by Henning Freund and Samuel Pfeifer, 35-51. Stuttgart: Kohlhammer, 2019.

Vitz, Paul C. Psychology as Religion. The Cult of Self-Worship. Grand Rapids: Eerdmans Publishing Co, 1977.

Walach, Harald. Beyond a Materialist Worldview. Towards an Expanded Science. London: The Scientific and Medical Network, 2019.

Waldenfels, Bernhard. Bruchlinien der Erfahrung. Frankfurt a. M.: Suhrkamp, 2002.

Waldenfels, Bernhard. Grundmotive einer Phänomenologie des Fremden. Frankfurt a. M.: Suhrkamp, 2006.

Waldenfels, Bernhard. “Die Anomalität von Kunstbildern und Patientenbildern.” In Bilderfahrung und Psychopathologie. Phänomenologische Annäherungen an die Sammlung Prinzhorn, edited by Sonja Frohoff, Thomas Fuchs and Stefano Micali, 32-51. Paderborn: Fink, 2014.

Walther, Gerda. "Zur innenpsychischen Struktur der Schizophrenie." Zeitschrift für die gesamte Neurologie und Psychiatrie 108 (1927), 56-85.

Walther, Gerda. Zum anderen Ufer: Vom Marxismus und Atheismus zum Christentum. Remagen: Otto Reichl, 1960.

Walther, Gerda. Phänomenologie der Mystik, 3rd edn. Olten: Walter Verlag, 1976.

Wapnick, Kenneth. “Mysticism and Schizophrenia." In Understanding Mysticism, edited by Richard Woods, 321-37. London: Athlone Press, 1981.

Weitbrecht, Hans J. Beiträge zur Religionspsychopathologie: insbesondere zur Psychopathologie der Bekehrung. Heidelberg: Scherer, 1948.

Welte, Bernhard. "Zur Lage der Fundamentaltheologie heute." In Auf den Spuren des Ewigen, edited by Bernhard Welte, 297-314. Freiburg: Herder, 1965.

Williams, Paris. Rethinking Madness. Towards a Paradigm Shift in our Understanding and Treatment of Psychosis. San Rafael: Sky's Edge Publishing, 2012. 